Article

\title{
Teaching on Mars: Some Lessons Learned from an Earth-Bound Study into Community Open Online Courses (COOCs) as a Future Education Model Rooted in Social Justice
}

\author{
Peter Shukie \\ University Centre Blackburn College, Blackburn BB2 5ER, UK; peter.shukie@blackburn.ac.uk
}

Received: 8 October 2019; Accepted: 27 November 2019; Published: 4 December 2019

\begin{abstract}
This paper begins with a playful contention that visions of future Martian colonies provide us not only with spaces for imagining extraplanetary activity. These futuristic considerations also offer us opportunity to reflect on education and technology in the here, planet Earth, and now. The focus of this research was the creation of a learning and teaching platform that was offered freely to anyone with the contention that 'anyone can teach, anyone can learn'. The platform itself was created using Moodle, as an open-source technology, and WordPress. The focus was on creating a space in which any individual, or group, might create learning spaces for free to share with others, based on social justice and challenging often exclusive, marginalising institutional practice. The project began as a critical response to institutional Massive Open Online courses (MOOCs) that promise widened access to knowledge, while rooted in conventional roles of where knowledge comes from and who teachers should be. The COOCs (Community Open Online Courses) project has now over 1500 registered course creators, and this paper discusses some of the key findings from an initial participatory action research process, involving twenty-five of the initial project users introduces some of the key findings from a research project. While decidedly earth-bound, the findings provide evidence of the benefits of widening who is involved in producing educational technology. The results suggest that widened access and greater awareness of power can help avoid continued inequality and marginalised knowledge as we look to a future that must include us all.
\end{abstract}

Keywords: technology-enhanced-learning; massive open online courses; community open online courses; pedagogy; critical pedagogy; Paulo Freire; informal education; higher education; gonzo pedagogy

\section{Introduction}

The clamour to embrace change has often begun with a feverish encouragement to seek in new technologies an escape from the challenges of the present. Rather than providing the necessary escape routes, it might be the case that unchecked, uncritical embracing of new technologies leads to the continuation of existing inequalities, exploitative practices (of the planet's resources, and of people on it) and rather than escaping, a reinforcing of the problems we seek to escape.

A recent publicity campaign by NASA generated posters that posited the recruitment of teachers, engineers and other professions for a new human society on Mars. Perhaps satirical, the potential for habitation beyond Earth continues to emerge from tech entrepreneurs such as Elon Musk (SpaceX), Richard Branson (Virgin Galactic) and Jeff Bezos (Blue Origin). The question the NASA campaign raises is the extent to which such seemingly incredible reimagining of a human future might be already rooted in the inequalities and divisive practices of existing society. By prioritising the concept of 
experts and specialists, the emphasis on a professional class separated from each other and the wider populace reflects an outdated and excluding educational model.

This paper argues that we do not need to wait for a becoming Martian future to see the ways that technological advancement becomes an amplifier [1] of existing privilege and exclusionary practice. Institutional Massive Open Online Courses (xMOOCs) provide an example of how technology is often resonant with the language of liberation and radical rethinking of how we teach and learn. Holford et al. [2] described how MOOCs would,

'change education out of recognition: partly by the new opportunities they present and partly by their threat to existing institutions, systems and structures'. (p. 569)

Selwyn [3] defines MOOCs as, 'best understood as a conduit for long running struggles over the nature and form of higher education in the digital age' (p. 191).

In xMOOCs, the notion of business models is integral [4] with large numbers of students offering market-economic opportunities. Huge datasets are also attractive to organisations seeking patterns of engagement and data-mining to generate future online models of education. A consequence is much research in which, 'learners' voices were largely absent' [5], (p. 214).

Such rhetorical claims mask the deeply ingrained common sense of institutional stakeholders and the social norms and conventions that they serve to enshrine in singular notions of what education is. Even while promoting transformation, such discourse further entrenches the necessity of the institutions as the home of knowledge, specialist educators as necessary and persistent roles, and students as always partially outside and inferior. We are not yet beyond Earth, but our developments on the planet continue to prioritise familiar groups while marginalising others.

This paper considers the values of creating learning spaces inspired by on Freirean popular education in which roles of teacher and student are transgressed. Additionally, knowledge is liberated from enclaves of ownership by a powerful class and reconsidered as a right and responsibility of all people.

The earth-bound study reflects on a practical response to inequality that came through the creation of Community Open Online Courses (COOCs), a noninstitutional educational platform that is open to anyone to create courses. This paper discusses some of the findings revealed over an 18 month long Participatory Action Research project into noninstitutional online learning. The platform was developed to explore the ways that a bridge might be created between formal and informal education. The intention was to establish two-way communication in which the community could inform the institutions while recognising the usual practice was one of outreach, where the institutions informed the community. Such a model of collaborative spaces between the heard and the unheard must be recognised as ambitious but essential if we are to generate meaningful, purposeful and realisable design of future educational technologies. The participatory nature of the research, the challenging questions at the root of the project, the amplification of participant voices and the seeking of new places beyond the walls of the institutions are all essential ingredients in revealing new possibilities. Both project ethos and research approaches are shaped by popular education as a necessary emancipatory concern when building new thinking that avoids automatically reinforcing social inequality. Through revisiting some powerful existing philosophies of common sense and Antonio Gramsci's thinking around this, the project also introduces gonzo education as a means of realising new voices and new ways of teaching and learning. A solid theoretical concern with education as the bedrock of societal change utilises popular education as an existing theory that can help create the foundations for a more just, inclusive and distributed form of education that benefits all, and not just a few on any planet.

Several hundred users and twenty-three research participants revealed that noninstitutional space is a rich and contested space. The influence of institutional ideology is not so easily thrown off but desire to seek freedom and autonomy pervades many experiences. This presentation highlights some of the key themes that emerge when learning platforms develop beyond the academy. 


\subsection{The Community Open Online Courses (COOCs) Project}

Decidedly earth-bound, the COOCs project demonstrates future-facing concerns around the means of addressing educational approaches to challenges of institutional education that often embeds division based on class, race and gender. The project developed from a community volunteer basis and was managed from my role as working class, Higher Education lecturer with an interest in informal education. Initial stages were funded by the Learning and Skills Improvement service (LSIS) in the United Kingdom, that supported interest in a noninstitutional learning platform open to anyone. LSIS was dissolved before the initial project completed, although there was a clear concern already emerging that any funding required an institution to receive support, regardless of the noninstitutional nature of the intended project. The dissolving of LSIS and the loss of funds is significant, as it led to the current structure of the research as an authentically nonaffiliated project, without funding and created and maintained by a community of informal educators. The platform was developed on Moodle, a cost-free open source virtual learning environment and was created with volunteer web developers. The Moodle course pages are accessed via a WordPress website, and hosting and domain names are funded by COOCs volunteers. Many of the initial courses created were used by formal educators using the platform for learning that could not be attached to their institutional courses. Alongside these developments in the hinterland between formal and informal education, there were multiple courses created by small/micro-sized community groups and individuals. All courses are characterised by there being no criteria for who can create courses, all courses being free of charge, and the stipulations for behaviour being covered by a code of conduct applicable to all site users. Multiple courses used blended learning approaches, with online materials and activities supported by, and embedded in, face-to-face learning encounters. Other courses were held entirely online, including courses that involved international collaboration between users across universities and colleges.

The emphasis of this paper is on the experiences of creating the platform as a collective endeavour. Exploring the types of individual courses and the experiences within each individual group or microcommunity is not presented here, but will form part of future research.

\subsection{Aims and Objectives}

The Project emerged form a planet with deep histories of social division, elitism, and systematic silencing of marginalised, though massively populous, sections of its inhabitants. This paper presents a selective focus on elements of a broader research project [6] related to the experiences encountered when creating a noninstitutional learning space. The overall research analysed the ways in which the COOCs platform was created, from inception and into use and development of the site [6]. Here, the emphasis is on those elements related to teaching and learning that better reveal the participant experiences when using a noninstitutional, open source and free access platform. A single question allows for each of the themes presented in the Findings chapter to emerge. This question is presented here as: What aspects of learning did participants encounter and report during their uses of the community open online courses platform?

To contextualise the question further, the emphasis on participant experiences is key, and while some background on theory is presented in the background, the key findings are derived from actual lived experiences as participants. This is in keeping with participant actions research (PAR) and serves to amplify often unheard voices in the creation of educational technology solutions. Although never intended as a blueprint for Martian education, the project explores the ways in which we might create an educational landscape that includes and develops from multiple, diverse communities on a planet that has struggled to do that.

\subsection{Concepts of Roles in Education across MOOC Types and COOCs}

Contemporary education theory is developing alongside technology and new approaches such as Massive Open Online Courses (MOOCS) developed in Canada and were influenced by connectivism, 
labeled as a learning theory for a digital age [7]. In these early models, the emphasis was on disruption of established institutional academic patterns of engagement, although largely dominated by people working in Higher Education. They are distinguished from institutional MOOCs, also known as xMOOCs, by their focus on knowledge generated by a network rather than distributed by a centre ground of professional experts. Fidalgo-Blanco [8] characterised the difference between the two thus,

' $x M O O C$ s are instructivist and individualist, use classic e-learning platforms and are based on resources, cMOOCs are connectivist and are based on social learning, cooperation and use of web 2.0'.

(p. 2)

While both $\mathrm{xMOOC}$ and cMOOC models shift learning beyond the campus walls, it is at the level of teacher, student and knowledge roles that the distinction between them both is most striking. Table 1 presents the roles of teacher, student and knowledge as a comparative between both types of MOOC and the roles of the each found in the COOC project platform.

Table 1. Establishing roles across cMOOCs, xMOOCs and COOCs [6].

\begin{tabular}{llll}
\hline & \multicolumn{1}{c}{ COOCs } & \multicolumn{1}{c}{ Connectivist cMOOC } & \multicolumn{1}{c}{ XMOOC } \\
\hline & $\begin{array}{l}\text { Open to anyone; create } \\
\text { course/network and make } \\
\text { Teacher Role } \\
\text { no professional or institutional } \\
\text { requirements }\end{array}$ & $\begin{array}{l}\text { Open-tendency toward } \\
\text { professional educators; } \\
\text { facilitated network }\end{array}$ & $\begin{array}{l}\text { 'Star lecturers'; institutional } \\
\text { affiliation; focus on transmission' } \\
\text { relocate institutional knowledge } \\
\text { in free access space }\end{array}$ \\
\hline \multirow{2}{*}{ Student/Learner } & $\begin{array}{l}\text { Free access; activities based on } \\
\text { course. Access online and real } \\
\text { world }\end{array}$ & $\begin{array}{l}\text { No entry criteria; varied activity } \\
\text { according to MOOC; } \\
\text { contribution to network }\end{array}$ & $\begin{array}{l}\text { No entry criteria; activities } \\
\text { based on MOOC leader tasks }\end{array}$ \\
\hline & $\begin{array}{l}\text { Knowledge a blend of } \\
\text { teacher/community-led. } \\
\text { Nondiscipline specific and wide } \\
\text { range of subject areas }\end{array}$ & $\begin{array}{l}\text { Knowledge created through } \\
\text { networks; student creativity } \\
\text { integral. }\end{array}$ & $\begin{array}{l}\text { Institutional disciplines and } \\
\text { courses (Abridged/tailored for } \\
\text { online transmission); } \\
\text { teacher-created }\end{array}$ \\
\hline
\end{tabular}

If we were to find ourselves on a new planet, the weaknesses of education systems that rely on only a few of the inhabitants to create, share and utilise new knowledge might seem obvious. While MOOCs offer a better distribution of knowledge, they remain confined to a narrow population of formally educated networks. Much of the required richness of experience, experimental applications and diversity in thinking would be left untouched and wasted. If we reflect on our own models of earthly education we see such wasteful inequality and this needs to be addressed by thinking beyond the same models that perpetuate this division. A theoretical framework based on identifying the necessity of social justice is necessary and argues for systematic change that goes beyond merely widening participation in divisive models that create such division.

\subsection{Theoretical Framework: Popular Education as a Prioritising of Community over Massiveness}

In attempting to create new ecologies of learning, the ethos of this project is related to Freirean popular education [9]. This is rooted in ideas of distributed knowledge, participation by all in the creation of intended learning, transgressive approaches to teacher/student roles and a resistance to massification [9]. Popular Education is a theoretical approach to education in which Paulo Freire, a Brazilian educator, provides much of the foundation. It is an approach rooted in empowerment and seeks to establish that knowledge and education are not neutral concepts and that a raised consciousness of where power lies is necessary to begin meaningful educational activity. In practical terms, popular education prioritises praxis, a concern with merging theoretical awareness with practical activity. Praxis requires participation, problem-solving and engagement of the communities involved in any learning programme [9]. It is significant in this paper as a means of addressing educational technology as a potential benefit if it includes the people it is meant to benefit. This distinguishes it from projects that are designed for people, the educational benefits anticipated by remote experts 
who define what these benefits might be while alienated from any supposed beneficiaries. Freire [10] was alive to a perception of such approaches being considered, ridiculous, mawkish, or unscientific if not anti-scientific' (p. 3). This is accepted as a risk, and one worth taking because remaining bound by only narrow interpretations of what research might look like, who it can involve and how results will be generated brings a greater risk of continued marginalisation, exclusion and silenced communities.

Crowther, Galloway \& Martin [11] define Popular Education as,

- 'Rooted in the real interests and struggles of ordinary people

- Overtly political and critical of the status quo

- Committed to progressive social and political change' [11], (p. 2).

The focus was on creating education that emerged from the value-based contexts of those immediately involved. The community forms around context-driven collaboration that could emerge anywhere. This contrasts to the MOOC model where institutions set course outlines/titles/facilitators at the outset and then offers a variation of interaction at the latter stages of participation. It is recognised that some MOOCs approaches suggest a distinct shift in how learning occurs online but that these still insist on the university as the barometer of engagement and with increasing concerns over business models and academic convention exercised through online learning manifestos [12].

Roles of teacher/student/knowledge provide a framework of challenge and indicate a difference between MOOCS and COOCs.

In selecting a Popular Education ethos, at the start of the project, the value of emancipatory practice was in the liberation of knowledge, the transgression of teacher/student roles and resistance to common-sense notions of banking education [9], in which knowledgeable teachers deposit knowledge into previously empty students.

The research recognised the dangers of what Biesta [13] calls a 'modern logic of emancipation' (p. 5). That is, that the goal of emancipatory education is to lift a veil from others and highlight their oppression. Such a position is challenged here, as it begins with an expectation that people are deluded or unconscious of their own lives. Instead, popular education allows that people are expert in their own lives [14]. The project takes from this that widening opportunity can allow multiple lives to speak for themselves. If we hope to build new planetary populations that function, a widening of who is involved is vital and a lesson we have missed in most of our own institutional infrastructures.

This does not suggest that community is a utopian space in which only positive action might occur. Instead, it recognises that a 'problem with community is ... that there are too many semantically justifiable interpretations' [15]. Martin [16] characterises 'the plural and unequal nature of communities' (p. 5) and both highlight no single notion of community exists. It is this disparate, fragmented and undefinable concept of community that necessitates a theoretical position that responds to this rather than seeks a homogenising coming together across massive populations. Paulo Freire [9] proposes that for education to act as a liberating challenge to injustice, it must actively engage with all people and seek to empower those with the least power in any society. For Freire, massification becomes a problematic term and in binary opposition to liberation (p. 148). Rather than offering increased access and widened participation, massification in popular education terms is a seeking of homogenisation and relies on the compliance of the many to the behest of a small group of experts.

\subsection{Popular Education as a Rethinking of Common Sense}

New planets might easily suggest a new way of thinking, and through reflecting on our own stunted thought processes, we can identify the barriers to change in our existing, prevailing systems. Common Sense suggests that prevailing conditions are simply 'the way things are' [17], (p. 49). A key foundation of the COOCs project was that it is possible to challenge the idea that knowledge creation must include distinct roles of teacher and student, and that these are terms and concepts naturally occurring. While teacher/student roles might change, common sense parameters define the extent to 
which this change can occur and ensure transformation is already controlled by institutionally-defined pre-existing limits.

Gramsci's [18] approach to common sense provides a complex space in which the acceptance of such dominant ideas is challenged. Watkins [19] defines Gramsci approach as a challenge to those leaders that, 'ground their assertions in what 'everybody knows' as just 'common sense" [19] (p. 106).

Similar approaches occur in educational theory and policy, such as Laurillard's [20] fixing of 'what it takes to learn' [20], (p. 7) that prioritises teachers as sole agents of change [12,20,21].

The COOCs project challenges an unquestioning acceptance of where teaching and learning occur and a Gramscian reading of common sense that is, 'not something rigid and immobile, but is continually transforming itself' [18], while also reflective of existing social inequalities. The relationship between common sense and good sense define wider power relationships within social/educational hierarchies that inform the way knowledge becomes embedded in culture and common usage.

New approaches for interplanetary repopulation can either resist such power-laden commonsensical concerns or remain defined by anterior conditioning that limits future direction. Evidence from the MOOC explosion of the 2011-16 period suggests that espousing transformational practice is less capable or interested in challenging presumptive concepts of an innate common sense. The value of the teacher, the location of the university as the heart of a centripetal meaning-making process remain predominant. The technological landscape in which the Community Project exists is complex and requires some reflection on how conflicting pressures are already embedded in the means of communication. Several approaches here describe how the techno-educational infrastructure is biased toward dominant common-sense readings.

Robinson [22] argues that a Gramscian reading of technology is 'ethico-political' [22], and views history as, 'the struggle of systems ... between ways of viewing reality' (p. 480). Historical analysis becomes the exploration of a, 'clash of ethico-political principles' and if these principles are left unchallenged we, 'can only describe historical events from the outside and cannot draw causal conclusions' [22], (p. 471). This might be considered equally true of our imagined future societies that we build while using only existing common-sense frameworks of the ways things must be. While Gramsci [18] might liberate thought/action from purely dominant conceptions, subaltern groups remaining 'within the framework set by the ruling class' [18], (p. 473) cannot begin alternative readings of reality. Robinson [22] argues that to be able to achieve autonomy and 'change the world' subaltern groups need to 'develop a new conception of the world ... not dependent on ruling class ideas' [22], (p. 473). A framework of technology and media that may appear neutral yet reproduces dominant value-systems provides a hurdle to emancipatory action not easily seen. The reality in which we educate takes place in spaces reflecting, 'corporate control of the media ... and 'common sense' assumptions which arise from committed exposure to material espoused by rightwing outlets' [22] (p. 480).

Technology and media tools lead to 'sub-altern lifeworlds ... territorialized and constructed by dominant elites' [22], (p. 477). Calls for educators' critical choices to become widened [23,24] must also include shifts from individual action to wider awareness of ownership and control of networks and systems.

Giroux [25] proposes ethics and political ideas become overshadowed by instrumental factors, arguing that,

'The consequence of the substitution of technology for pedagogy is that instrumental goals replace ethical and political considerations, diminishing classroom control by teachers while offering a dehumanizing pedagogy for students'. (p. 124)

In this approach, the instrumentalism of technology prioritises means over ends of education and reflects Parchoma's concerns of technology as a route to standardisation. Mirrlees and Alvi [26] argue MOOCs as Taylorisation processes prioritise business models and replicate economic inequality. They propose that 'citizens not corporate and governmental elites' [26], (p. 68) should hold the power of choice. Hall and O'Shea [27] describe a creeping neo-liberal common sense across the public sphere (p. 4) that reduces teacher-student to provider-customer contexts and infuse the language of education with neoliberal philosophies. 
The practicality of a corporate logic is already established according to Buchanan [28] who argued that,

Google is effectively the common sense understanding of what using the internet actually means ... one writes with a pen, makes calls with a phone, and searches the internet. [28], (p. 14)

A pervasive 'search engine culture' [29], (p. 150) has effectively transformed the utopian vision Tim Berners-Lee [29] had of learning by sharing in an 'enormous, unbounded world' (p. 34). Instead, a culture of mass-market-seeking corporate entities ignore state legislation/censorship and prioritise commercial exchange [28].

Gramsci's [18] 'philosophy of praxis' [18], (p. 640), argues for,

'a criticism of 'common sense' basing itself, however, on common sense in order to demonstrate that 'everyone' is a philosopher and that is not a question of introducing from scratch a scientific form of thought ... but renovating and making 'critical' an already existing activity'. [18], (p. 638)

The call to become critical is to begin a 'criticism of the philosophy of the intellectuals' [18] and to challenge what might otherwise be a residual, common knowledge beyond question.

Such a position informs the approach of this research to a 'critical philosophy of technology' [24], (p. 74). The contention here is that popular education finds roots in Gramsci's call for a philosophy of praxis [30,31] with critical participation a fundamental part of conscientisation [9]. It is through lived participation, not theoretical discourse alone, that new models can be created that challenge dominant hierarchical practices. The dialogic approach is theoretically and practically significant in avoiding hierarchical and distancing mechanisms that prioritise institutional responses. Through this approach to praxis, localised, small-scale activity can inform concepts of teacher, student and knowledge [14].

As with Gramsci, praxis in popular education is considered the starting point for 'wider learning' [30], (p. 25). In ascertaining what wider learning means, a crucial distinction between Freire and Gramsci appears in relation to high and popular knowledge. Gramsci considered through criticising common sense that good sense (p. 660) would follow which in turn paves the way to higher philosophical thought. Gramscian approaches lead to an,

'... advocacy of the need for subaltern groups to gain the means to critically appropriate established 'high status' cultural forms and knowledge with a view to moving from the margins to the center'.

[30], (p. 23)

Freirean interest lies in promotion of the popular, while recognising that, '.. the popular constitutes only the entry point to knowledge and is not the be all and end all of the learning process' [30], (p. 24).

In establishing that knowledge operates on a trajectory, from popular to wider learning, the significance for community-based projects is that knowledge can be both relevant in its immediate location and able to become enriched through reflection. This is significant in arguing that courses created on the Community Project include 'higher' learning despite their being located outside 'Higher Education'. It highlights that movement away from centripetal expertise to include distributed networks of knowledge creation [14], (p. 46) is possible.

Commentators, such as Nagle [32] highlights the influence technology has had on political ideologies. Rather than old models of political certainty, clearly defined by ideology and readily fitted within binaries of left and right, techno-politics is fractured and fragmentary. Nagle describes how the vision of a left leaning technostructure would be distributed and open, shattering old hierarchies and structures of power (p. 3). Writing around the emergence of an Alt-Right and Alt-Left web-based ecology of violent imagery and vicious mockery, Nagle highlights how, "notions of popular taste maintained by a small creative class are now perpetually outpaced by viral content from obscure sources' [32], (p. 3). As well as not being the 'utopian vision they [positive commentators on the networked society] had hoped for' [32], (p. 3) this vicious ecology also highlights the complexity of a coming age of multidimensional, multiuser communications in sectors such as Education. 
If we consider the future of education as merely a resurfacing of roadways with the destination already decided then the possibility of transformation is lost. Establishing ever more ambitious means of reaching out, either through enabling massive courses or interplanetary exploration, is meaningless if the ends are not part of intended transformation. The motivation for the COOCs project requires an acceptance that 'the way things are' is not beyond question. As Nagle [32] identifies, the way things change will also be less than utopian. To identify how the COOCs project witnessed diverse engagement, it was crucial that participation was prioritised and foregrounded in how the project was created, lived and researched.

\subsection{Challenges to Community as a Meaningful Space for Learning}

Any challenge to the existing holders of power is not likely to be met with open arms, either in the desperate race to the stars, and perhaps more tellingly, back here on Earth. Knox [33] argues that the COOCs project is, 'isolating educational activity from an external world imbued with threats and liabilities' [33], (p. 174) and instead positions education as, 'a transcendent, sterilised activity disconnected from the contaminations and disputes of the populace' [33], (p. 174). Writing from the position of an institutional, university-bound MOOC, Knox's position suggests that communities are themselves apart from the world, suggesting the institutional MOOC as more authentically tied to 'contaminations and disputes'. Quite how such a rarefied and self-selecting MOOC creation team as that operated within the institution better realises this authenticity than the communities creating beyond the campus is not developed. Downes [34] speaks of the connectivist MOOC that it also expels any notion of community and instead focuses on the network. Downes asserts that,

'communities embed knowledge and standardize practice ... MOOCs disrupt existing patterns of thinking and introduce people to new connections and new ideas'. [34], (p. 30)

Across both positions, the $\mathrm{xMOOC}$ and cMOOC advocates dismiss community as a meaningful space for radical change, new ideas and alternate visions for education. The implication in both is that massiveness is itself a significant changing agent and numerical size will be enough to create transformational and emancipatory change. The ethos of Freire, that massification is subsuming and standardising is felt more by those left in the mass than those in power that decide what direction the mass should travel. Popular Education suggest instead a prioritising of community over massiveness. This does not suggest that community is a utopian space in which only positive action might occur. Instead, it recognises that a 'problem with community is ... that there are too many semantically justifiable interpretations' [15], (p. 5). Martin [16] characterises 'the plural and unequal nature of communities' [16], (p. 5) and both highlight no single notion of community exists. It is this disparate, fragmented and undefinable concept of community that necessitates a theoretical position that responds to this, rather than seeks a homogenising coming together across massive populations. Paulo Freire [9] proposes that for education to act as a liberating challenge to injustice, it must actively engage with all people and seek to empower those with the least power in any society. For Freire, massification becomes a problematic term and in binary opposition to liberation [9], (p. 148). Rather than offering increased access and widened participation, massification in popular education terms is a seeking of homogenisation and relies on the compliance of the many to the behest of a small group of experts.

\section{Materials and Methods: Establishing an Earthly Context}

Creating a researcher position can immediately destroy intentions of collaboration and equality if we adopt research positions separated from the people and contexts we hope to research. Regardless of the inevitable vertical isolation travel to Mars might require, the research into COOCs had to occur within and with the communities involved. This section details a research methodology that did not seek a higher ground of manipulated objectivity but instead embraced an often messy but authentic earthly reality. 
The COOCs platform continues to run and has over 1500 registered users globally, with Figure 1 highlighting a distribution of use that highlights that the greatest concentration is in the United Kingdom, as was initially intended. The global distribution of registered users reflects some appeal of the platform although the focus of the research here has been centred on an initial user group of twenty-five participants, located in the United Kingdom and all involved in the first iteration of the project. The research methodology applied was participatory action research (PAR), a qualitative concern with the experiences and perspectives of those involved in the creation of the project. PAR is often considered a contentious approach [35], (p. 191) in standard research models. This is largely based on the emphasis being on research 'with' people, not research 'on' people. Recognising that PAR does not rigorously follow the scientific method, which Stringer [35] argues inevitably misses the purpose of scientific inquiry and reduces it to little more than quantitative generalisations that often miss the significance of diverse experience and activity [35], (p. 193). It is the participatory nature, the willingness to seek knowledge beyond expected places and a responsiveness to new places knowledge might arise that makes PAR a suitable model for this research. Herr and Anderson [36] argue that PAR, 'arises out of a critique of the very assumptions, values and approaches that ground traditional social science, university based research' [36], (p. xii). The decision to employ PAR stems from an understanding that if we are to seek new ways of conceiving of education, the inclusion of technology and the ways these might respond to contemporary challenges of sustainability, then we need to vary our methods of inquiry. Schön [37] considers the value of this approach to research being one of knowing-in-action and one that can escape the purely institutional contention of what this might be [37], (p. 27). The summary of such knowing in action means that,

'The new categories of scholarly activity must take the form of action research. What else could they be?' [37], (p. 31)

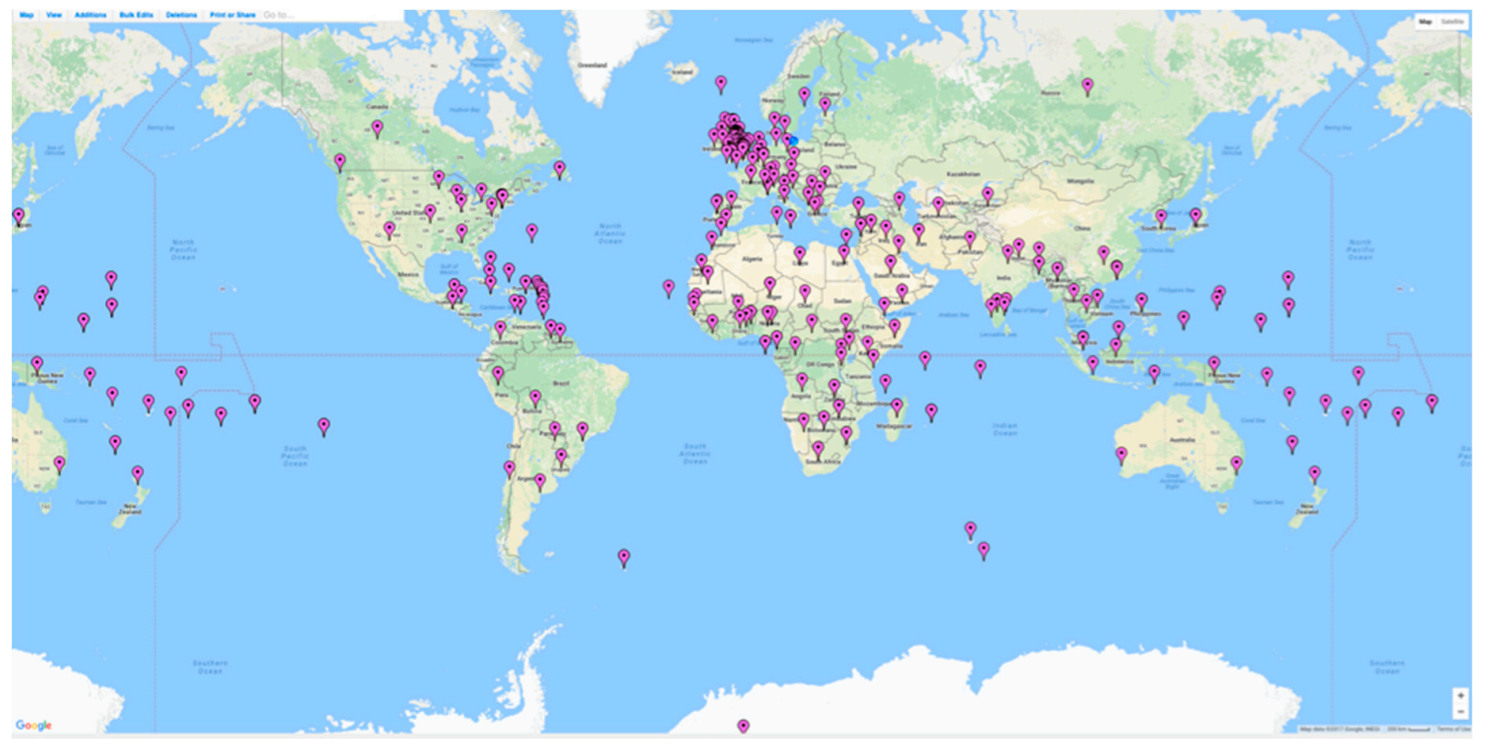

Figure 1. A map showing the distribution of registered course creators on the COOCs site.

As the focus of this research was on what happens, and how people respond as a project develops, participatory action research was a necessary choice, if a courageous one based on its challenges to traditional research methods. Ontologically, PAR highlights 'different ways of conceiving knowledge and its relation to practice' [38], (p. 4). A purposeful ontology necessitates 'courage' to 'speak and act in ways that are often contested' [38], (p. 4). The ontological imperative is on research that leads to transformative action, as Gergen and Gergen [38] describe, it is,

'not the task of the action researcher to describe the world as it is, but to realize visions of what the world can become'. [39], (p. 167) 
We can develop this to reflect that while teaching on Mars provides no immediate problem for extraplanetary travelers it does sharpen our minds to what would be most valuable. Looking afar helps us reframe what could be differently here to enable all sectors of society to engage and help shape meaningful, positive education.

Stringer [35] recognises that in purely scientific method terms, such participant engagement leads to accusations of subjectivity [35], (p. 193). This, he identifies, creates a tension between research that seeks to 'provide knowledge that will make a difference to people lives' [35], (p. 193) and that which is accepted by much research convention. Here, the assertion is that by including people in the research we generate purposeful evidence to support meaningful change that offer tangible routes to making a difference.

Previous research that explores educational technology and popular education [40] demonstrates that researcher-centred models are possible. The research position of this paper differs from such positions [41,42] by emphasising coresearch and coparticipation as necessary atrributes to allow marginal and unheard voices to find space to be included.

\subsection{Cyclical Research Process}

A characteristic of all action research is that it employs a cyclical approach to the research. This is true of PAR and here three cycles framed the research. The findings and discussion relate to the collected summarising of all three cycles of the research that occurred over an 18-month period. Details of each cycle are presented separately elsewhere [6], and the goal of this paper is to clearly articulate an overview of the findings on completion of the research project.

\subsection{Sampling}

Twenty-five separate participants took part in the research project. The story of the research required the involvement of all participants, with their input, experience and activity the bedrock of the findings. Bryant [43] describes participants in PAR as a 'collaborative resource' (p. 113) with no one voice prioritised over another. It is recognised that PAR results in research, that Stringer [35] reflects, leads to participants having, 'much more control than is usually accorded participants in a study' (p. 55).

Participant investment was both individual, and collective around developing the platform. Wimpenny's [44] model, as seen in Table 2 illustrates how authentic participation was negotiated.

Table 2. Illustrating the 'Negotiating of Authentic Participation' adapted from [44], (pp. 93-96).

\begin{tabular}{ll}
\hline \multicolumn{1}{c}{ 'Key Elements' of PAR Engagement } & How These Were Realised in the Sample Frame \\
\hline $\begin{array}{l}\text { Relocation of power, primary researcher } \\
\text { responsibilities }\end{array}$ & $\begin{array}{l}\text { The participants involved in development of } \\
\text { processes-open invitation to development } \\
\text { meetings/decision making. Research processes } \\
\text { dialogic. }\end{array}$ \\
\hline Development of a sound dialectic & $\begin{array}{l}\text { Multiple approaches to engagement implemented to } \\
\text { avoid silencing participants/reifying others. Cycles } \\
\text { developed based on participant exchange. }\end{array}$ \\
\hline Generation of knowledge and understanding & $\begin{array}{l}\text { Knowledge generation sought at both the collective } \\
\text { and the individual level (without assumption these } \\
\text { would coincide). }\end{array}$ \\
\hline $\begin{array}{l}\text { Pevelopment of shared quality criteria to ensure } \\
\text { validity }\end{array}$ & $\begin{array}{l}\text { Participation included decision making across all } \\
\text { levels of platform design. Code of conduct created } \\
\text { collectively; findings allow } \\
\text { disagreement/upset/compromise as valid and } \\
\text { informative inclusion. }\end{array}$ \\
\hline
\end{tabular}

Three parameters are applied when describing the participant sample. These are, recruitment, criteria and engagement. 
Criteria: Although open to anyone to participate, an emergent set of collective criteria developed. Participants

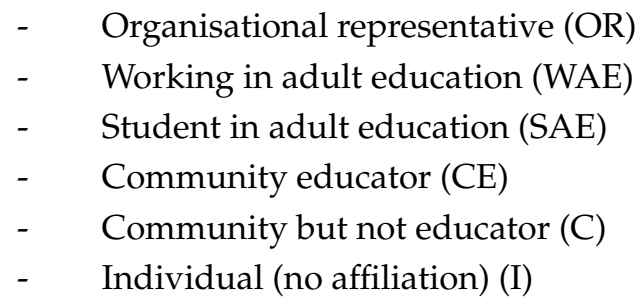

The categories emerged during the research cycles and help in establishing some of the responses. Establishing those taking part in terms of category proved useful in highlighting influences of prior educational experience. Examples of individuals from each category are presented in Appendix A, and these utilise pseudonyms that allow for an individual approach to each participant while maintaining anonymity.

\subsection{Methods of Data Collection}

The range of data collection reflected the necessity of ongoing, often asynchronic, engagement of participants. These included social media posts, blogs and personal journals as well as course materials, interviews and focus groups (Appendix B provides an overview of data collection methods across three cycles). To alleviate subjective researcher bias, Nominal Group Technique (NGT) and Delphi Technique (DT) approaches were applied. In these techniques, groups of participants are provided with stimulus questions about their experiences and asked to discuss collectively and provide an agreed collective response about key themes and considerations. They differ in that NT takes place in a real-world space, synchronously, and generates analogue responses on flipchart/paper. DT involves a similar model, but takes place in online space and occurs asynchronously with a corresponding generation of digital artifacts in response. Both approaches transfer the creation of final submissions from researcher interpretation to coresearcher consensus. These points are then included in future individual and smaller group discussions to consider contrasts and disagreement, within broader positions of agreement.

\subsection{Data Analysis Considerations}

To develop a practical response to a participatory research process, it was necessary to employ diverse opportunities for participants to engage and inform the discussion. To establish robustness, these methods to be reflected against criteria of validity that demonstrated a continued concern with ensuring what occurred was no less significant, in fact more so, than might be revealed in traditional quantitative data analysis. McNiff \& Whitehead [45] suggest identifying a sphere of influences and responding to how each might impact results. Figure 2 highlights these including processes of $\mathrm{PhD}$ study in creating the research for a thesis, the impact of theoretical frameworks, the input from participants alongside my own ethos/values and the effects of this research felt by its proximity to multiple educational sectors and those involved in them.

The range of data presented included audio files, images, video, webpages, paper presentations, a series of transcripts from conversations, focus groups and interviews alongside various elements of course materials observed on the COOCs platform. While an initial consideration had been the NVIVO qualitative analysis software, it was necessary to engage in a more complex manual approach to thematic analysis. Influenced by the McNiff \& Whitehead spheres of influence, as seen in Figure 2, this included returning to participants to establish validity for themes claimed through the data and generating example evidence for the interior validity of each theme presented.

Ethics are crucially important in any such research. This research followed the protocols of the university through which the research was conducted, and involved initial discussion and the provision 
of participant information sheets for all that responded to the request for participation. Consent forms were necessary for participation in qualitative data collection and media release forms were necessary where participant materials were included in the discussion.

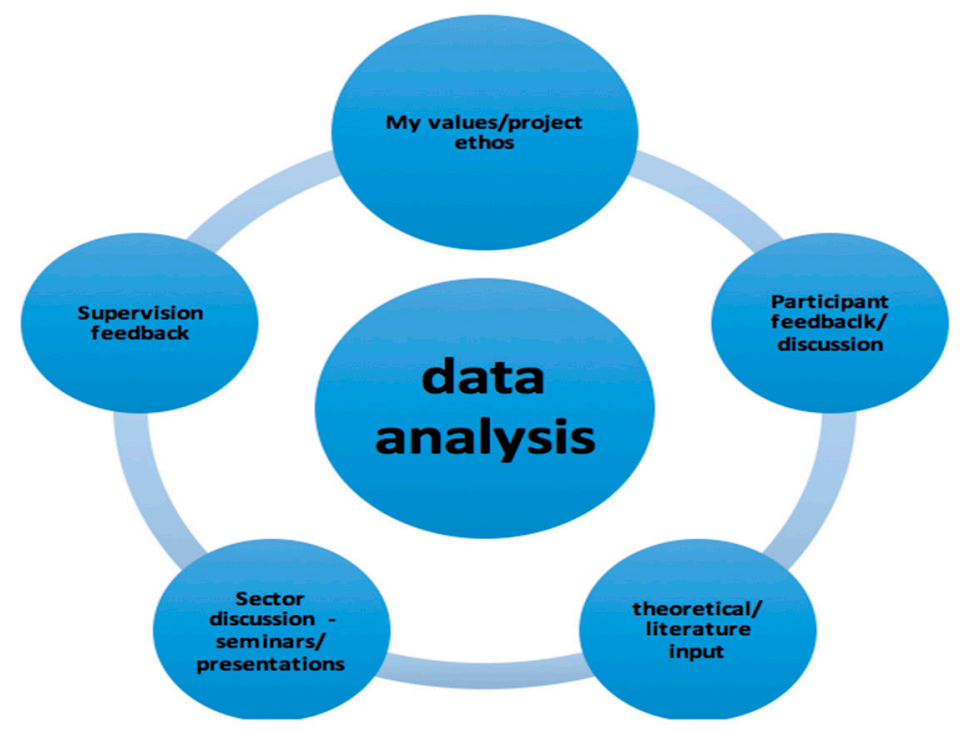

Figure 2. Aspects used in generating standards of judgment when validating the data. [45].

\section{Results and Discussion}

Across this section, the emphasis is on a dualistic contention that what was reported/uncovered and what this means must be considered together. This approach is essential in supporting the ways that participants were at once the generators of data, while also coresearchers in establishing the significance of the themes they helped generate. Such an approach contends that avoiding elevated, vertiginous researcher positions is not only valid, but generates the collaboration necessary for creating fair new worlds. The summary of the themes, as seen in Table 3, emphasises that much of what is revealed is based on a resistance to being defined by others. Recognising the significance of collaborative input, these findings suggest that planning for universals, such as education, must also adopt universality in the opening dialogue that shapes such plans.

Table 3. Summary of the themes from the research.

\begin{tabular}{cl}
\hline Key Themes & \multicolumn{1}{c}{ Simply Put } \\
\hline Gatekeeping \& Vulnerability & $\begin{array}{l}\text { Institutional practices shape how things move and develop and so influence even those moves that } \\
\text { seek alternatives to them. Vulnerability becomes a feature assigned by the powerful to those they } \\
\text { consider powerless and helps them define who can and who cannot take part. }\end{array}$ \\
\hline Pyramids of control & $\begin{array}{l}\text { Various levels of awareness and concern exist about the technological infrastructure in which we live. } \\
\text { It is necessary to give serious consideration to the ways in which different individuals and groups } \\
\text { view the technologies that we ask them to be involved with. The concern that 'we rarely contemplate } \\
\text { how our surface world is propped up from below by darkness' (Assange, ([46], p. 3)) should not be ignored } \\
\text { and must form part of the structures we create/promote/use and the knowledge we include. }\end{array}$ \\
\hline \multirow{3}{*}{ Challenging Common Sense } & $\begin{array}{l}\text { To begin to develop learning outside institutional norms requires a questioning of the } \\
\text { common-sense assumptions we rely on. To do this, a reason to question these common-sense } \\
\text { assumptions comes from recognising the failings such models have for many. The more we benefit } \\
\text { from the common sense concepts, the less likely we are to challenge them. This section proposes a } \\
\text { gonzo education based on the evidence from participant experiences. }\end{array}$ \\
\hline Philosophies of Practice & $\begin{array}{l}\text { To develop educational alternatives a crucial concern is establishing our philosophies-in-practice. } \\
\text { This moves away from distanced theoretical awareness, metaphors and espoused discourse of } \\
\text { philosophies. Instead, uses of technology and approaches to how we teach/learn are based on lived } \\
\text { philosophies rooted in action. }\end{array}$ \\
\hline
\end{tabular}




\subsection{Gatekeeping and Vulnerability}

In earth-bound and other projects, there is the likelihood of a tension between those creating new world and the current holders of the wealth and power that can facilitate it. The experiences of creating the COOCs noninstitutional space proved challenging largely because of the funding framework for developing new projects. The initial bid had been explicit about creating a noninstitutional space and the funding body, perhaps aware of its own imminent demise, agreed this as a viable project to support. However, a contradiction appeared immediately as to allocate funds an institution was required to accept this support, and with that an auditable trail of invoices, payment and institutionally recognised governance was insisted upon. This led also to the creation of a steering group that was based on established and pre-existing institutional partners. The steering group was made up of local government representatives, third sector organisations and a community volunteer agency. The input of this group was disruptive as it was clear that each member was representative but not participating in the actual project itself. As they were each bound by their own organisational milestones, these were prioritised over the creation of any new spaces for innovation. An example came in the steering group suggestion of mandatory Mathematics and English Language courses being prioritised as courses on the platform. This was explicitly tied to government funding concerns over these functional skills in formal education. The representatives did not have the resources to create the courses, nor any actual requests from groups they represented. This prioritising based on a nonpresent influence, in this case government formal educational policy, was common to all suggestions raised by representative governance. A crucial consideration for project design and education as authentic collaborative process was enmeshed in the question of who has the right to assign vulnerability. The implications of representation without participation echoed across course development. There was evidence of a disconnect from an active course creation group, and an influential but nonengaged representative steering group. The pervasive approach of first selecting a group to govern immediately distinguished between types of participation and created a disruptive hierarchy. The functional Maths and English courses attracted no users and proved emblematic of the intentions of elite but isolated power forced onto others, based on authoritarian wish-lists rather than on purpose decided through dialogue.

\subsection{Pyramids of Power}

A second key feature of the steering group was the concern of vulnerability that representatives allocated to their own service users. Each organisation was resistant to course creation by microgroups because of perceived vulnerability and an insistence on access being granted only via the governance structure. This inferred vulnerability led to statements around the representatives' presence in governance being one of mediation, although they could not access potential participants in their own user groups because of their concerns around vulnerability. This led to an automatic disempowering of intended users that had decisions made on their behalf without any access to making actual decisions themselves. Figure 3 was submitted to the research forum by a participant, defining a metaphor of 'building windmills in the shadow of the power station'. Discussion beyond the steering group was characterised by a frustration that the project could not be realised because of existing power structures creating barriers to development. While vulnerability can be a necessary concern that avoids harm, to have this allocated by one group over another based solely on access to power proved disempowering and alienating. Being represented without opportunity to respond and shape perceptions of self provided no basis for meaningful engagement and instead led often to feelings of exclusion.

An additional concern was one of an ironic inefficiency that was imposed on the project by having to employ a web developer to create the initial platform. Despite having access to volunteer web developers who were involved in the project, the funding regulations meant an obligation to employ a registered business able to provide auditable invoice trails. Not only expensive, this proved time-consuming, of poor quality and necessitated prolonged discussions to share an ethos with a commercial organisation with limited interest in the project and a desire to complete as quickly as 
possible. Once in this relationship, we found all tasks came at a cost, fixes were not completed and the platform was inoperable for most of this initial period.

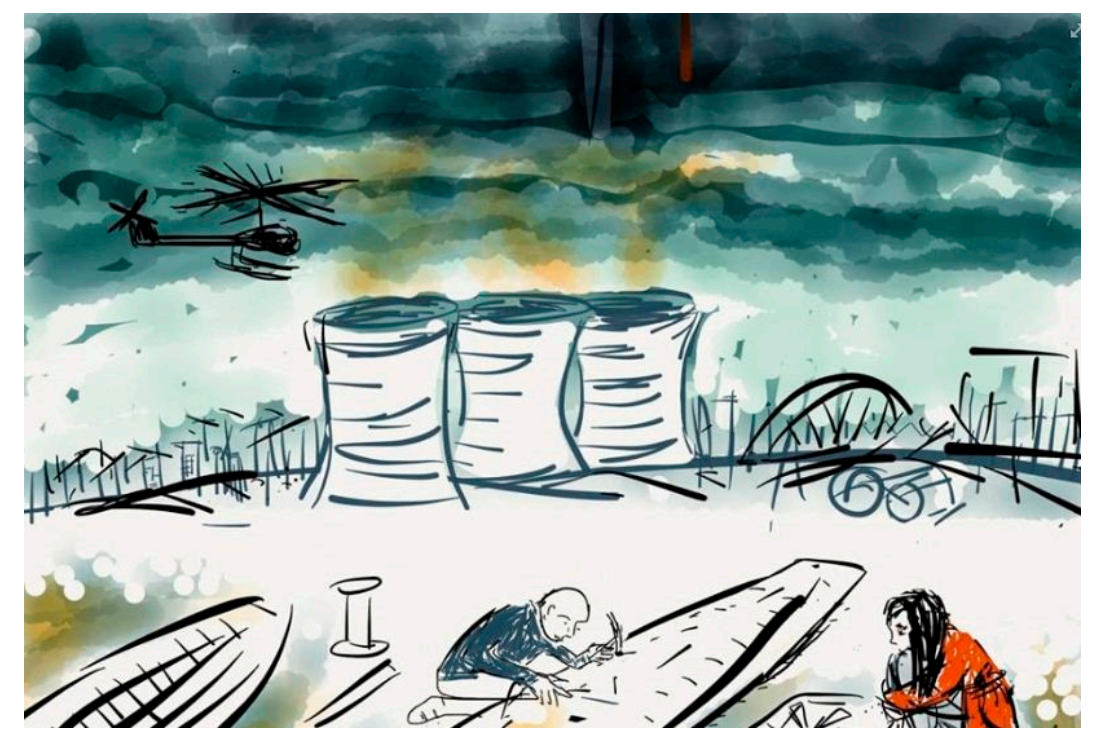

Figure 3. Building Windmills in the Shadow of the Power Station.

Every suggestion made, or amendment required to fix problems, came with calls for additional finance, curt email responses and invoices as the primary form of reply. Without expertise of legality, business processes or consumer rights, the engagement with technology proved alienating and part of another language, another codex. It was the language and practice of commercial practice that shaped the relationship and threatened the viability of the project. It was not that we wanted things for free, but even after payment for a nonoperational platform, the route to question, ask for fixes or engage in discussion was one clouded by technocratic obstacles and procedures.

The inclusion of technology met many of the rhetorical and transformative claims of the institutional technologists. New tools, production above consumption, widened networks and enriched communities fed into by distributed others all appeared attractive and compelling. To reach these, a space of commerciality had first to be overcome and to do this a necessary accommodating of commercial awareness and compliance is necessary.

McLaren [47] argues that,

'Technological advances are functionally integrating us to the ideological circuits and global imperatives of the transnational capitalist class, prompting us to perform our identities according to the hidden transcript of the neoliberal agenda: to create consumer citizens through a comprador class cyber-citizenry who serve as sentinels that ensure the promulgation of a colonial mentality'. [47], (p. 264)

Responses here indicate an often-incomprehensible global matrix that participants were increasingly aware of and that developed as a critical reflection of our socioeducational landscape. A pyramid metaphor, as seen in Figure 4, came initially from a participant who argued that,

"digital education is somewhere we find ourselves, nobody teaches it, they just lay it out there, expectantly, they don't provide a guide to the pyramid we are part of, the privacy and ownership issues, our place in the big picture ... nobody teaches that". (Participant, Tony)

In the focus group, I drew a pyramid and asked how this might be structured. The significance of the pyramid comes from participants' concerns that the Project existed in a hierarchical and often concealed landscape. The five layers highlight influential, partially concealed strata that were only partially understood or defined. 
The consensus was that individual action was at the top and that this reflected smallness and having most exposure. Negative images of control and ownership prevailed and the creation of each layer came with descriptions of distance and vulnerability. The web developer/commercial layer was mid-point and reflected an amalgam of market-driven concerns and corporate frameworks. Tony (focus group) argued that the web developers,

"... are there because society creates a greed is good approach, they respond to that, a money first ethos that squashes social good".

Participant Kim responded with an acceptance of the pyramid, but with less clarity over how it was structured,

"The pyramid I get, but not what we are in it, are we bottom or top? Who is the rest? I know that people own my data, is that true of the project too? But who are the rest and are they national or what? We are so tiny it can be off-putting, frightening ... who is seeing us or using us for something we don't know". (Kim, focus group)

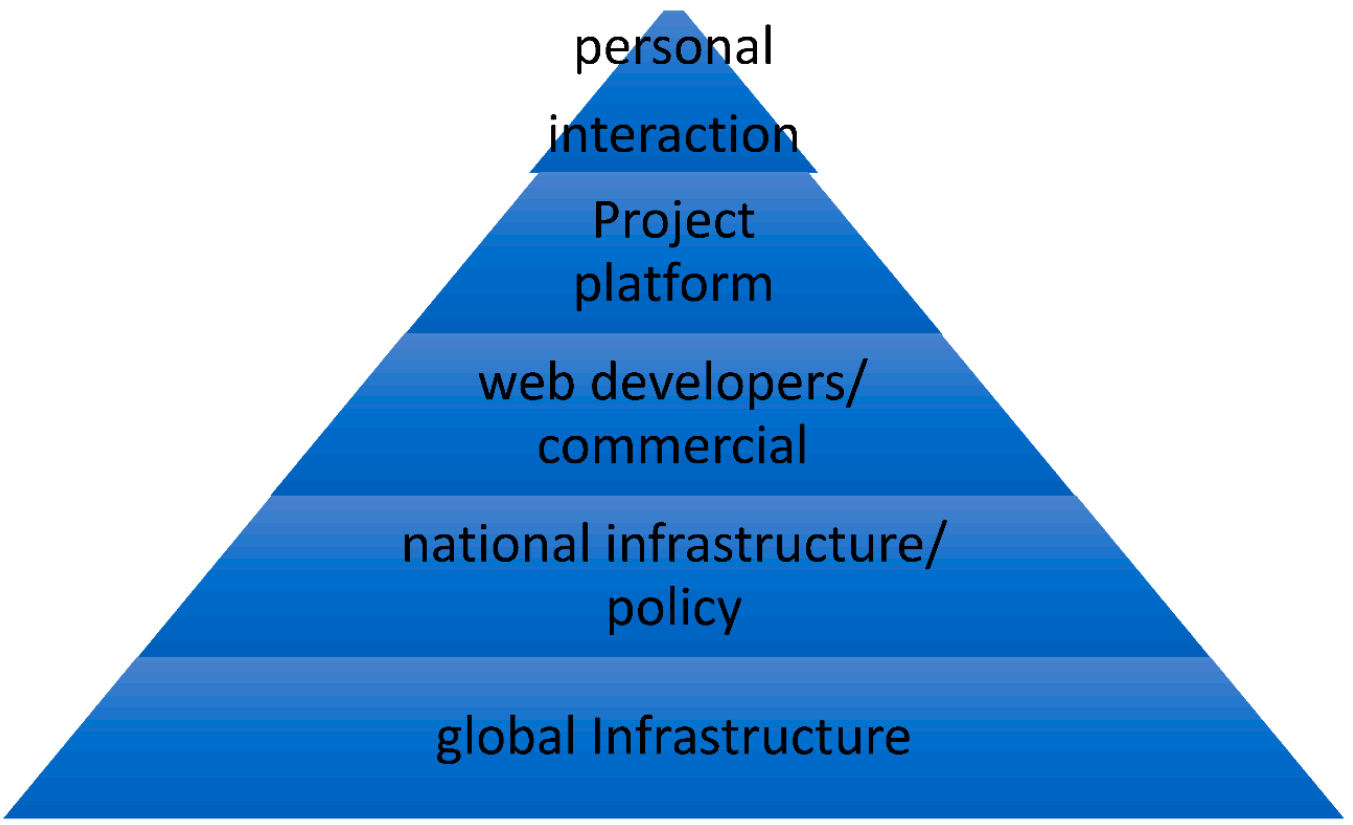

Figure 4. Pyramid of influence and control depicted by participants.

The fear of the technology that had permeated infrequent users was now permeating us all as we recognised this as an ecology of which we had limited expertise and from which we were alienated. The promise of a Freirean emancipatory space, where courses would provide opportunity to interact and share relevant, 'really useful knowledge' [48] seemed lost amidst our own sense of helplessness. Even the most supportive participants commented that the process was 'appalling'. I feel sick with it, it's just so bloody frustrating, we need some help, otherwise I cannot spend any more [time] on it' (participant, Jo).

As the project developed, the gatekeeping draw of visible institutions was complicated by our conceptions of technology as more than tools, exceeding the influence of how our own skills and access might allow us to engage. From participants who worked in education and those who had no exposure, technology provided a depth that proved threatening and invisible. The awareness reflects [46] description that, 'we rarely contemplate how our surface world is propped up from below by darkness' [46], (p. 2). Different events sparked fears of a concealed influence. There were clear and powerful advantages for employing educational technology and these drove participation in the project. It was also clear that an increasing awareness of the complexity of technological infrastructure needed 
to be part of design and reflection. Technology enables connection, and with connectivity comes issues of existing power and the necessity to navigate within these structures. A reliance of accepted norms and practices is shrouded by notions of a prevailing common sense that, left unchallenged, led to the continuation of existing hierarchies and inequalities. Even when the result of such pervasive common sense is clearly problematic an adherence to the well-trodden path means such problems are ignored. Future models that maintain such dialogue-free, entrenched positions of power will inevitably continue to reinforce a status quo regardless of planetary location.

\subsection{Challenging Common Sense: Toward a Gonzo Education that Modernises Static Visions of Educational Practice}

Developed form a Gramscian and popular education concern with challenging power-laden concepts of common sense, participant responses provide a practical response to what a new approach to learning might be. Gonzo education emerged from participant discussion as a response to the ways they might challenge existing educational structures in which they were not easily included. Even where participants were formal educators in universities or colleges, the gonzo approach arose as they sought spaces in the margins, between institutions and community. The term gonzo is taken from Hunter S Thompson and remodeled from Thompson's gonzo journalism. Bladen's [49] discussion around gonzo lectures links gonzo to American slang for a stage of intoxication [49], (p. 2). Most tellingly, the application Bladen gives to its use is its 'rebellion against conformity to ... an unjust political and social system' [49], (p. 2). This rebellion, or at least alternative approach, characterised many courses on the COOCs platform that proved diverse, idiosyncratic and often highly specialised responses tailored to nuanced and micro-sized groups. Gonzo education developed from participant consideration that learning is idiosyncratic, works better when infused with immediate interest and has the teacher-learner involved in mutually lived involvement with what is studied.

It reflected learning that developed from specialist concerns that might have wide involvement but could be temporary, or emphasise concern with a marginal viewpoint or way of thinking.

One example is a schizophrenia support group developed from families that sought a space that did not represent them as either a medical condition or a social problem. Instead, they found a network of families that created 'Hearing Allowed'. Based on the notion that hearing voices was natural and not necessarily problematic, their support began without preconditions of medical or social problematising. Such responses first reflect on their own experiences, then challenge predominant narratives and finally begin new ways of thinking that prioritise their own lives and requirements. Bladen [48] located gonzo lectures as a way of improving institutional practice by prioritising lecturer performance, involving humour and modelling irreverence. The evidence of the COOCs platform suggested that more realisable freedom existed when leaving constraints of formal educational lectures all together. The restrictive lecture practices are not the result of an individual's professional skill, but the result of restraining convention and adherence to models of active-passive, producer-consumer. Regardless of content, a lecture based on binaries of lecturer and student alone can only reinforce the power distribution that reifies the institution and diminishes other knowledge spaces.

The COOCs platform argues for a widening of what learning and teaching look like. Choices were often emergent, beginning with no set curricula and developed as collectives. This led to many courses being incomplete, random and described as 'building sites' (Jodie, participant). This caused some participants to reflect on the process as often unclear and frustrating, and some called for a set of standards to be developed. Yet, despite this, courses continued. They looked often abstract and had intermittent use, periods of intense development followed by periods of seeming abandonment.

A growing sense of learning being inherently messy, of motivation waning and reforming, of multiple changes in direction, seemed natural and positive. It took a frame of mind that did not continually refer to institutional measures. In most cases, there were no measures beyond those at course level. A Code of COOCs was decided collectively and was based around positive and supportive involvement rather than specific models of behaviour. Crucial components of formal education, such 
as attendance, assessment, grading, achievement, retention and accreditation were abandoned and replaced by fluid, emergent concepts of what it meant to learn that differed across groups.

Course creation also occurred in hinterlands, between the inside and outside of the institutions. One participant's course 'Making the Invisible Visible' was a series of practices that developed from degree art courses. Recognising the emphasis on product, on exhibition, the COOCs course allowed an emphasis on those processes of creativity that were not easily measured, not neatly packaged for validated and externally measured programmes. The role of the student is altered through such experimentation. They become involved in a codesign, cocreation role of participation. It clearly cannot work for everything but is significant in the expectation of responsibility and engagement that required the development of gonzo as a reflection of these changes.

Gonzo education provided a useful, often playful experimentation around types of educator and purpose of learning. Terms for the educator developed and included 'schizo-leader' (participant, Mavis) and 'garden-guru' (participant, Andrea). While these perhaps mischievous terms depart from professional or formal terminology, both definitions embody a serious concept. Gonzo education suggests a means of discussing education that:

- Operates from an understanding of the blurred boundaries and the messy hinterlands of institutional, semi-institutional and noninstitutional education. An approach that recognises and describes the interplay between these spaces.

- That allows for multiple authors, designers and creators of learning without any a priori concern over rights to develop these.

- Describes a discursive space that does not require adherence to any theoretical or philosophical model -in this it reflects the actual lived reality of any educational experience.

- Additionally, does not deny the influence/application of theoretical models but that they include the actual practices/experiences of those involved.

- Involves the educator and students in the discussion of any exercise or reflective practice of an educational event. This removes the danger of actions being interpreted by analytical processes that exclude the intent of those involved.

- Begins with means and ends as essential reflective points. These may not be clear or agreed but help clarify the foundations on which any learning process is built.

- Contends that participation is better than perfection, that being engaged in shaping knowledge holds more value than accessing already wholly developed concepts produced by others.

It is through establishing the potential for newness and fluid responses that gonzo education affords a space in which to discuss education that is not bound by convention. The pyramids of control represented an often daunting and intimidating technological ecology with deeply embedded concepts of power shaping possible futures. The liquid nature of a gonzo response stems from human responses that repurpose learning within a technostructure. This is less easily defined, more difficult to generalise and standardise but perhaps more open to the demands of the diverse and fast-flowing environment that technological advance brings.

\section{Conclusions}

A playful concern with teaching on Mars still provides a platform for serious reflections for what common sense assumptions we rely on when we envisage alternate futures. The project reflected the issues of a universal common-sense in even the most sympathetic and supportive definitions of community, as well as in denigrating and patronising ones. Significance comes from understanding that authentic projects seeking redistribution of power and knowledge must begin with a willingness to lose what power they currently have. The xMOOC models highlight a rhetoric of redistribution and reality in which reification and centripetal ownership remains. Future research in technology and community spaces must be prepared to promote institutional risk and courage when discussing the future shape of change. If transformation is considered a meaningful and desirable pathway, this must 
have depth to consider funding, organisation, location, redistribution of power and influence and a genuine will to consider 'letting go'. This research focused on a microcosm of 25 participants on a platform experienced by 1500 others. Even in this small example, the range of views, the contradictions, revealed the impossibility of neat consensus.

Accepting messy and nuanced approaches as the norm, not as ill-defined copies of an institutional ideal, is crucial. This avoids the errors of seeking mass models of education that are based in enduring market-driven ideology but do not respond to the vast diversity across local, national and global communities. Several initiatives grew alongside the COOCs Project and demonstrated similar interests in free, community and online education. The findings here help to illustrate the complexities and difficulties faced by those not in supported, institutionally resourced space. As such, this research offers valuable outsider perspectives as approaches to porous universities and free and cooperative education emerge and re-emerge. The fluidity of courses indicates rather than seeing fragmentation as the result, we might find in these approaches a more developed responsiveness to changing, and entirely new, conditions.

Across the Project, the influence of the institution has been felt and proved difficult to escape. Reaching the end of this small-scale research, research into learning within institutions appears as well-developed and complex. Learning without institutions, and between institutions and community as equal partners, is much less researched and appears widely misunderstood. Where this does occur it often remains rooted in conventions of institutional norms. And such discourse, even when based in social justice, reinforces centripetal knowledge. The COOCs Project highlighted a rich and often fervent desire to play and uncover idiosyncratic approaches to learning. Approaches to the community begin with concerns over what has been left undone, of the gaps left unfilled by solutions to problems that come not from communities but hierarchical contentions over what communities require. This research proposes renewed efforts at research and practice that begin without the prioritising of institutions, whether they are empathetic and supportive or not. An authentic practice requires freedom of creative potential that is not drawn back to an established centre. The idea that professionals can control what education will look like is compelling and easier to arrange and manage than a wide-open approach in which expertise might be distributed. While widening participation and service learning may generate symbolic approaches to reaching out, if we continue to prioritise only those people that become educators via professional and institutional courses, diversity is impossible. Becoming educator, from a COOCs perspective, asks whether it might be possible to create learning and teaching that emerges beyond institutions. Whether the desolation of Mars, or the rich complexity of Earth, the imperative for designing education must include all areas and approaches and not only those ready-made and professionalised.

It might be that what occurs is the loss of the binary, that outside and inside become increasingly meaningless. A porosity of borders will help develop learning and teaching practices that are based on mutuality and collective endeavor. Reframing learning/teaching/knowledge does not give voice; instead it must insist on voices being heard. Instead of pockets of silence, this research revealed many voices that required only space to be heard. Nothing of the vicious ecologies that Nagle [32] described was apparent, and perhaps the localised and involved communities created on the platform meant such brutal, anonymised and fleeting engagement was rendered impossible. Through meaningful participation and developing purposeful learning, the tendency toward cynicism and destructive response is lessened.

A key claim of the Project is that learning occurs in multiple places, and is an innate and integral feature in all aspects of society. The need is for recognition, not of inspiration. Institutions may play a role in helping develop spaces, but as partners in a multiway exchange of views. The ability of the institutional space to attract resources can help the communities in which they sit. This must be as hubs of learning, not as charitable outreach programmes that insist on power lying at the centre. Spaces of learning are complex enough without the additional consideration of learning in outer-space. What this earth-bound study reminds us is that empowerment comes with a redistribution of power and 
a willingness to let go of power for many in elite and privileged positions. The extent to which this can be facilitated by notions of social justice rather than conflict will define what our newly emerging societies will look like, both here and amongst the stars.

Funding: This research received no external funding.

Acknowledgments: This research received no funding. Gratitude is given to Sue Cranmer, and Don Massey, both of Lancaster University, UK, for their supervision and guidance of this project. Additional thanks are given to Jim Crowther, Edinburgh University and Murat Oztok, Lancaster university for their careful reading and considered comments on the final summary of the project.

Conflicts of Interest: The authors declare no conflict of interest.

\section{Appendix A}

\begin{tabular}{|c|}
\hline Stuart (OR and CE) \\
\hline $\begin{array}{l}\text { Stuart was originally an organisational representative for a national charity with } \\
\text { responsibility for the local authority district. The charity worked with the elderly and } \\
\text { people in assisted living spaces. Stuart was the only one of the ORs to continue } \\
\text { as participant after the initial Steering Group folded. He continued as a Community } \\
\text { involved participant as he worked with groups outside his professional role in } \\
\text { establishing spaces for people to meet and talk. He ran small group sessions and } \\
\text { while not an educator he was involved in running small, informal knowledge- } \\
\text { sharing events in the town. He created one course in this cycle, although it was } \\
\text { not published due in part to technical issues. }\end{array}$ \\
\hline Age: $45-54$ \\
\hline Jodie (WAE) \\
\hline $\begin{array}{l}\text { Jodie worked as an Art Lecturer at a local college based Higher Education } \\
\text { institute. Her engagement happened from the start and although asked to take } \\
\text { part in the steering group, Jodie declined although making regular meetings with } \\
\text { myself about the technology issues and the platform design. Jodie made three } \\
\text { courses based around the processes of creating art. These informed the wider } \\
\text { aspects of her formal courses but were not part of the required learning. Jodie } \\
\text { used her experiences to generate some research she used in conferences around } \\
\text { making the invisible visible. Although all three courses were published, these were } \\
\text { partially lost through technical failure. }\end{array}$ \\
\hline Age: $35-44$ \\
\hline $\begin{array}{l}\text { Kerry (I) Kerry came to the launch event having been invited to accompany her } \\
\text { friend. Kerry was currently working in public transport, but had been a volunteer } \\
\text { teaching assistant in primary schools. Kerry's initial interest was in developing } \\
\text { learning based around the ways that children learned in schools and letting } \\
\text { parents and grandparents access this at home. It was an issue she had } \\
\text { experienced in her own family and she created two courses that were published. } \\
\text { These lost materials through technical issues although Kerry recreated them at a } \\
\text { later stage of the project. Kerry did not consider herself an educator and had no } \\
\text { experience in online learning. She described herself as being motivated through } \\
\text { seeing the way social media had changed the way people communicated. }\end{array}$ \\
\hline Age: $18-25$ \\
\hline $\begin{array}{l}\text { Alex (CE) Alex came to the Community project after reading about it in an online } \\
\text { blog. He was based in Scotland and ran a free education initiative that operated a } \\
\text { website, a blog, and ran free lectures in third spaces in cities across the UK. Alex } \\
\text { was interested in helping to develop the concept of free education and he created } \\
\text { courses in economics, austerity and mental health. Alex is described as educator } \\
\text { here, although he describes having no formal qualifications at the time of the } \\
\text { research. His vast knowledge and breadth of literature was often commented } \\
\text { upon by other participants, and Alex considered his education was self-taught and } \\
\text { from informal meetings with professionals, academics and the speakers/writers } \\
\text { using his free education site. }\end{array}$ \\
\hline Age: $35-44$ \\
\hline
\end{tabular}

George (OR/SG)
George worked for a Community Volunteer organisation in Recruitment and
management. He was on the board of governors for several local colleges and
was invited to the SG by one of these. He considered his organisation would be
able to coordinate the recruitment of volunteers for the CP. George did not
register for the CP or attend the focus group. He consented to an interview and
considered his role as "advocate for multiple groups and potential partner
organisations".
Age: $45-54$

Figure A1. Outline of types of participants. 


\section{Appendix B}

Table A1. Overview of Data Collection Methods.

\begin{tabular}{|c|c|c|c|}
\hline Data Collection Method & Occurrences in Cycle One & Occurrences in Cycle Two & Occurrences in Cycle Three \\
\hline Journal/Blogs & $1 \times$ main author & 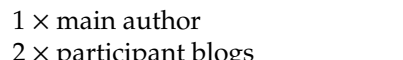 & $1 \times$ main author \\
\hline Social Media & No use & $\begin{array}{l}23 \times \text { group discussions } \\
8 \times \text { individual posts }\end{array}$ & $\begin{array}{l}13 \times \text { group discussions } \\
17 \times \text { individual posts }\end{array}$ \\
\hline Interviews (one-to-one) & $3 \times$ interviews (spoken) & $\begin{array}{l}11 \times \text { interviews (spoken) } \\
4 \times \text { online interviews (video) } \\
2 \times \text { online interviews (typed) }\end{array}$ & $\begin{array}{l}12 \times \text { interviews (spoken) } \\
3 \times \text { online interviews (video) } \\
5 \times \text { online interviews (typed) }\end{array}$ \\
\hline Focus groups & $2 \times$ focus groups & Not used & Not used \\
\hline $\begin{array}{l}\text { Nominal Group } \\
\text { Technique (NGT) }\end{array}$ & Not used & $2 \times \mathrm{NGT}$ & $2 \times$ NGT \\
\hline Delphi Technique (DT) & Not used & $1 \times \mathrm{DT}$ & $1 \times \mathrm{DT}$ \\
\hline Documentary & $\begin{array}{ll}\text { - } & \text { Original } \\
\text { website platform } \\
\text { - } \\
\text { Minutes of steering } \\
\text { group minutes }\end{array}$ & $\begin{array}{l}\text { - } \quad \text { Cocreated website platform } \\
\text { Images from participants } \\
\text { (individual) }\end{array}$ & $\begin{array}{l}\text { - } \quad \text { Cocreated website platform } \\
\text { Images from participants } \\
\text { (group) }\end{array}$ \\
\hline
\end{tabular}

\section{References}

1. Toyama, K. Technology as Amplifier in International Development. In Proceedings of the 2011 I-Conference, Seattle, WA, USA, 8-11 February 2011; pp. 75-82.

2. Holford, J.; Jarvis, P.; Milana, M.; Waller, R.; Webb, S. The MOOC Phenomenon: Toward lifelong education for all? Int. J. Lifelong Educ. 2014, 33, 69-572. [CrossRef]

3. Selwyn, N. Massive Open Online Change? Exploring the Discursive Construction of the MOOC in Newspapers. High. Educ. Q. 2015, 69, 175-192. [CrossRef]

4. Haggard, S. The Maturing of the MOOC: Literature Review of Massive Open Online Courses and Other Forms of Distance Learning; UK Government, Department for Business, Innovation \& Skills. The Stationery Office: London, UK, 2013.

5. Veletsianos, G.; Sheperdson, P. A Systematic Analysis and Synthesis of the Empirical MOOC Literature Published in 2013-2015. Int. Rev. Res. Open Distrib. Learn. 2016, 17, 198-221. [CrossRef]

6. Shukie, P. A Participatory Action Research Investigation Into An Open, Online Community Project Exploring How Teaching And Learning Occur In A Non-Institutional, Non-Specialist, Technology Enhanced Learning Environment. PhD Thesis, Lancaster University, Lancaster, UK, 2018. Available online: https://doi.org/10. 17635/lancaster/thesis/287 (accessed on 16 September 2019).

7. Siemens, G. Connectivism: A learning theory for a digital age. Int. J. Instr. Technol. Distance Learn. 2005, 2, 3-10.

8. Fidalgo-Blanco, A.; Sein-Echaluce, M.; Garcia-Penalvo, L. From Massive Access to Cooperation: Lessons learned and proven results of a hybrid $\mathrm{xMOOC/cMOOC} \mathrm{pedagogical} \mathrm{approach} \mathrm{to} \mathrm{MOOCS.} \mathrm{Int.} \mathrm{J.} \mathrm{Educ.}$ Technol. High. Educ. 2016, 13, 1-13. [CrossRef]

9. Freire, P. Pedagogy of the Oppressed: 30th Anniversary Edition; Continuum: London, UK, 2005.

10. Freire, P. Education and Community Involvement. In Critical Education in the New Information Age; McLaren, P., McLaren, P., Eds.; Rowan \& Littlefield Publishers: Lanham, MD, USA, 1999.

11. Crowther, J.; Galloway, V.; Martin, I. Popular Education: Engaging the Academy; NIACE: Leicester, UK, 2015.

12. Bayne, S.; Ross, J. Manifesto for Teaching Online 2016. Available online: https://onlineteachingmanifesto. wordpress.com/the-text/ (accessed on 8 February 2018).

13. Biesta, G. Don't be fooled by Ignorant Schoolmasters: On the role of the teacher in emancipatory education. Policy Futures Educ. 2017, 15, 52-73. [CrossRef]

14. Wiggins, N. Critical Pedagogy and Popular Education: Toward a unity of practice. Stud. Educ. Adults 2011, 43, 34-49. [CrossRef] 
15. St. Clair, R. On the Commonplace: Reclaiming Community in Education. Adult Educ. Q. 1998, 49, 5. [CrossRef]

16. Martin, I.S. New Times: New Directions? Adults Learn. 1993, 4, 143-145.

17. Landy, M. Socialist Education Today: Pessimism or optimism of the intellect? In Rethinking Gramsci; Green, M., Ed.; Routledge: London, UK, 2011.

18. Gramsci, A. Selections from the Prison Notebooks; Lawrence \& Wishart: London, UK, 1972.

19. Watkins, E. Gramscian Politics and Capitalist Common-Sense. In Rethinking Gramsci; Green, M., Ed.; Routledge: London, UK, 2011.

20. Laurillard, D. Teaching as a Design Science: Building Pedagogical Patterns FOR Learning and Technology; Routledge: London, UK, 2012.

21. Laurillard, D. Technology Enhanced Learning as a Tool for Pedagogical Innovation. J. Philos. Educ. 2008, 42, 521-533. [CrossRef]

22. Robinson, A. Toward an Intellectual Reformation: The critique of common sense and the forgotten revolutinary project of Gramscian theory. Crit. Rev. Int. Soc. Political Philos. 2005, 8, 469-481. [CrossRef]

23. Kanuka, H. Understanding e-Learning Technologies-in-Practice through Philosophies-in-Practice. In Theory and Practice of Online Learning; Anderson, T., Elloumi, F., Eds.; Athabasca University Press: Athabasca, AB, Canada, 2008; pp. 91-118.

24. Parchoma, G. Toward Diversity in Researching Teaching and Technology Philosophies-in-Practice in e-Learning Communities. In Handbook of Research on Methods and Techniques for Studying Virtual Communities: Paradigms and Phenomena; Daniel, B., Ed.; IGI Global: Hershey, PA, USA, 2011; Volume 1.

25. Giroux, H. The University in Chains: Confronting the Military-Industrial Academic Complex; Paradigm Publishers: Boulder, CO, USA, 2007.

26. Mirrlees, T.; Alvi, S. Managing with MOOCS: Taylorising academia, deskilling professors and automating Higher Education. J. Crit. Educ. Policy Stud. 2014, 12, 45-73.

27. Hall, S.; O'Shea, A. Common Sense Neoliberalism. Soundings 2013, 55, 9-25. [CrossRef]

28. Buchanan, I. Deleuze and the Internet. Aust. Humanit. Rev. 2007, 43, 1-19.

29. Berners-Lee, T. Weaving the Web: The Original Design and Ultimate Destiny of the World Wide Web; Harper Collins: New York, NY, USA, 2000.

30. Mayo, P. Gramsci, Freire and Adult Education: Possibilities for Transformative Action; Zed Books: London, UK, 1999.

31. Allman, P. Gramsci, Freire \& Illich: Their contributions to education for socialism. In Radical Approaches to Education; Lovett, T., Ed.; Routledge: London, UK, 1988.

32. Nagle, G. Kill All Normies. Online Culture Wars from 4CHAN and Tumblr to Trump and the Alt-Right; Zero Books: Hampshire, UK, 2017.

33. Knox, J. Digital Culture Clash: "Massive" education in the e-learning and digital cultures MOOC. Distance Educ. 2014, 35, 164-177. [CrossRef]

34. Mackness, J.; Bell, F. Rhizo14: A rhizomatic learning cMOOC in sunlight and in shade. Open Praxi 2015, 7, 25-38. [CrossRef]

35. Stringer, E. Action Research, 3rd ed.; SAGE: London, UK, 2007.

36. Herr, K.; Anderson, G. The Action Research Dissertation; Sage: London, UK, 2005.

37. Schön, D. Knowing-in-Action: The new scholarship requires a new epistemology. Change 1995, 27, $27-34$. [CrossRef]

38. Reason, P.; Bradbury, H. The Sage Handbook of Action Research; Sage: London, UK, 2008.

39. Gergen, K.; Gergen, M. Social Construction and Research as Action. In The SAGE Handbook of Action Research; Reason, P., Bradbury, H., Eds.; SAGE: London, UK, 2008; pp. 159-171.

40. Tygel, A.F.; Kirsch, R. Contributions of Paulo Freire to a critical data literacy: A popular education approach. J. Community Inform. 2016, 12, 108-121.

41. Zeigler, M.; Paulus, T.; Woodside, M. Understanding Informal Group Learning in Online Communities Through Discourse Analysis. Adult Educ. Q. 2014, 64, 60-78. [CrossRef]

42. Gray, B. Informal Learning in an Online Community of Practice. J. Distance Educ. 2004, 19, $20-35$.

43. Bryant, I. Action Research and Reflective Practice. In Understanding Educational Research; Scott, D., Usher, B., Eds.; Routledge: London, UK, 1998; pp. 106-119. 
44. Wimpenny, K. Participatory Action Research: An integrated approach toward practice development. In New Approaches to Qualitative Research; Savin-Baden, M., Howell-Major, C., Eds.; Routledge: London, UK, 2010.

45. McNiff, J.; Whitehead, J. Doing and Writing Action Research; Sage: London, UK, 2009.

46. Assange, J.; Appelbaum, J.; Müller-Maghun, A.; Zimmerman, J. Cyberpunks: Freedom and the Future of the Internet; OR Books: New York, NY, USA, 2012.

47. McLaren, P. Pedagogy of Insurrection: From Resurrection to Revolution; Peter Lang: New York, NY, USA, 2015.

48. Lovett, T. Radical Approaches to Adult Education: A Reader; Crook Helm: Beckenham, UK, 1998.

49. Bladen, C. The Gonzo Lecture: Counterculture in the classroom. Compass J. Learn. Teach. Univ. Greenwich 2010, 1, 35-41. [CrossRef]

(C) 2019 by the author. Licensee MDPI, Basel, Switzerland. This article is an open access article distributed under the terms and conditions of the Creative Commons Attribution (CC BY) license (http://creativecommons.org/licenses/by/4.0/). 